\title{
Antifungal efficacy of botanicals against major postharvest pathogens of Kinnow mandarin and their use to maintain postharvest quality
}

\author{
Md. Jameel JHALEGAR ${ }^{1}$, Ram Roshan SHARMA ${ }^{1 *}$, Dinesh SINGH ${ }^{2}$
}

\author{
${ }^{1}$ Div. Postharvest Technol., \\ Indian. Agric. Res. Inst., \\ New Delhi-110 012, India \\ rrs_fht@rediffmail.com \\ 2 Div. Plant Pathol., \\ Indian Agric. Res. Inst., \\ New Delhi-110 012, India
}

* Correspondence and reprints

Received 25 July 2013 Accepted 12 November 2013

Fruits, 2014, vol. 69, p. 223-237 (C) 2014 Cirad/EDP Sciences All rights reserved DOI: 10.1051/fruits/2014012 www.fruits-journal.org

RESUMEN EsPañol, p. 237

\section{Antifungal efficacy of botanicals against major postharvest pathogens in Kinnow mandarin and their use to maintain postharvest quality.}

Abstract - Introduction. Kinnow is an important citrus crop grown in India, which suffers from several postharvest diseases during storage. Hence, an attempt was made to combat such diseases with the botanicals Aloe vera, Eucalyptus and Ocimum on Kinnow mandarin to prolong its availability for a longer time. Materials and methods. For this, in vitro and in vivo studies were conducted. The poisoned food technique was used for in vitro studies, and, for in vivo studies, Kinnow fruit were pre-inoculated with pathogens (Penicillium digitatum and P. italicum), treated with different botanicals, then stored at $(5 \pm 1)^{\circ} \mathrm{C}$ temperature and $85-90 \% \mathrm{RH}$. Results and discussion. Our results indicated that all botanicals inhibited the growth (colony diameter) of both pathogens over untreated PDA plates, but the inhibition was the strongest by Aloe vera extracts. Similarly, under in vivo conditions, all botanicals influenced the decay incidence, decay loss, lesion diameter, respiration rate, ethylene evolution and physiological loss in weight, but Aloevera was the most effective. All the botanicals were able to retain postharvest quality of Kinnow fruits without any adverse effect on quality parameters such as TSS, TA and ascorbic acid. Under in vivo conditions, the incidence of Penicillium italicum was higher than $P$. digitatum; however, it was the reverse under in vitro conditions. Conclusion. Thus, it is evident from our studies that botanicals have the potential to control green and blue mold without causing any injury or harmful effects on Kinnow mandarin; botanicals can be recommended as a safe method for extending its storage life while maintaining fruit quality at the same time.

India / Citrus / mandarins / fruits / postharvest control / biological control / respiration rate / keeping quality

Efficacité antifongique de certaines espèces botaniques contre d'importants agents pathogènes d'après-récolte chez la mandarine Kinnow et leur utilisation pour maintenir la qualité après-récolte.

Résumé - Introduction. La mandarine Kinnow est une importante variété d'agrume cultivée en Inde, sensible à plusieurs maladies d'après-récolte pendant son stockage. À cause de cela, une tentative a été faite pour combattre de telles maladies de la mandarine Kinnow à l'aide d'espèces botaniques telles que Aloevera, Eucalyptus et Ocimum et prolonger ainsi sa disponibilité. Matériel et méthodes. Des études in vitro et in vivo ont été entreprises. La technique de nourriture polluée a été utilisée pour des études in vitro et, pour les études in vivo, les fruits de Kinnow ont été pré-inoculés avec des agents pathogènes (Penicillium digitatum et $P$. italicum), traités avec différentes espèces botaniques, puis conservés à la température de $(5 \pm 1)^{\circ} \mathrm{C}$ et $85-90 \%$ de HR. Résultats et discussion. In vitro, nos résultats ont indiqué que chacune des espèces botaniques testées a empêché la croissance (diamètre des colonies) des deux pathogènes dans les boites traitées par rapport aux boites non traitées, mais l'inhibition a été la plus forte avec les extraits d'Aloe vera. De même, dans les conditions in vivo, toutes les espèces botaniques ont influencé l'incidence de la pourriture due à Penicillium sp., les pertes occasionnées par le pourrissement, le diamètre de lésion, le taux respiratoire, l'évolution de l'éthylène et les pertes de poids physiologiques, mais Aloevera a été le plus efficace. Les trois espèces botaniques testées ont pu maintenir la qualité après la récolte des fruits de la mandarine Kinnow sans effet inverse sur des paramètres comme les solides solubles totaux, l'acidité à titrable et l'acide ascorbique. Dans les conditions in vivo, l'incidence de $P$. italicum a été plus forte que celle de $P$. digitatum, cependant, l'inverse a été constaté dans des conditions in vitro. Conclusion. Nos études ont montré de façon évidente que les espèces botaniques peuvent contrôler la moisissure verte et bleue due à Penicillium sp. sans entraîner de dégâts ou d'effets néfastes sur la mandarine Kinnow ; elles peuvent être recommandées pour prolonger la durée de stockage de ce fruit tout en maintenant simultanément sa qualité. Inde / Citrus / mandarine / fruits / lutte après récolte / lutte biologique / taux de respiration / aptitude à la conservation 


\section{Introduction}

Postharvest diseases account for about 50\% losses in fruits stored in poor storage conditions, especially under high humidity [1] Citrus fruits are among the crops susceptible to postharvest diseases caused by fungi. The most important fungi causing postharvest diseases include: Penicillium spp., Aspergillus spp., Alternaria spp. and Rhizopus stolonifer [2]. The control of plant diseases is still mainly dependent on the use of chemical fungicides. Synthetic fungicides such as thiabendazole, imazalil and sodium ortho-phenylphenate have been used traditionally to control the postharvest diseases, but their excessive use, complemented with high costs, residues in plants and development of resistance, has left a negative effect on human health and the environment. Further, withdrawal of some chemical pesticides, such as benomyl and captan, for control of postharvest diseases in the USA [2] and ethylene dibromide for sterilization of Queensland fruit fly in Australia, is a clear signal that new technologies and new fungicides for control of plant diseases are needed. The United States of America Environmental Protection Agency has classified benomyl as a possible human carcinogen, which can also act as a chronic and reproductive toxicant However, worldwide 'organically grown' fruit, which has not been treated with fungicide, is becoming popular among consumers. Under these circumstances, an alternative method of disease control for Kinnow mandarin without the use of synthetic chemicals is urgently needed.

Some environmentally friendly plant extracts have been shown to have great potential as an alternative to synthetic fungicides [2]. Recently, the antimicrobial activity of some higher plant products that are biodegradable and safe to human health has attracted the attention of microbiologists in the control of plant disease, but the actual use of these products for the control of postharvest pathogens of fruits generally, and in particular for citrus pathogens is, however, still limited. Among the safer alternatives to synthetics, use of plant products has attracted researchers for the management of diseases of several fruits [3]. The major purpose of our research was to extend the marketable period of 'Kinnow' mandarin through approaches such as using botanicals to control or inhibit the pathogens causing postharvest diseases in Kinnow mandarin, as the fruits are susceptible to postharvest diseases such as green mold and blue mold caused by $P$. digitatum and $P$. italicum, respectively, which reduce its availability for a longer time in the market.

\section{Materials and methods}

\subsection{Experimental site and fruit material}

This study was conducted in the Division of Postharvest Technology, Indian Agricultural Research Institute, New Delhi, India, during 2010-2012 in the fruiting season (December-February) of Kinnow mandarin. For in vitro and in vivo studies, three different botanicals were used: Eucalyptus, Ocimum and Aloe vera. The Kinnow fruits were obtained from a private orchard, sorted and graded before undergoing any treatment in the laboratory.

\subsection{Isolation and identification of the pathogens from Kinnow mandarin fruit samples}

\subsubsection{Pathogens}

Penicillium digitatum and Penicillium italicum were originally isolated from Kinnow fruits and were cultured for 1-2 weeks on potato dextrose agar (PDA) at $25^{\circ} \mathrm{C}$. Conidia of $P$. italicum and P. digitatum were harvested by adding $5 \mathrm{~mL}$ of sterile, deionized water $\left(\mathrm{diH}_{2} \mathrm{O}\right)$ containing $0.05 \%$ Triton X-100 to the Petri dish. Colonies were rubbed with a sterile glass rod and the conidial suspension was passed through two layers of cheese cloth. The suspension was diluted with water to an absorbance 
of 0.1 (optical density) at $425 \mathrm{~nm}$ as measured with a spectrophotometer, a density that comprised about $10^{6} \mathrm{conidia} \cdot \mathrm{mL}^{-1}$ [4].

The identification of the fungal isolate was carried out by microscopic observation according to the appropriate taxonomic key and description. Continuous re-isolations were carried out on PDA slants to maintain the pathogenicity of the inocula.

\subsubsection{Preparation of plants for extracts}

Leaves of Aloe (Aloe barbedensis), eucalyptus (Eucalyptus sp.) and holy basil (Ocimum sanctum) were selected for the study. The leaves were collected from a herbal garden and washed under running water, to get rid of dirt, insects and plankton. They were dried overnight in the laboratory with an electric oven at $40{ }^{\circ} \mathrm{C}$. One hundred grams of the material (leaves) were pulverized by an electric mixer and preserved in labeled glass bottles that were sealed until use.

\subsection{Preparation of botanicals}

Plant extracts were prepared by macerating fresh plant parts with an equal volume of sterile distilled water $(1: 1, \mathrm{w} / \mathrm{v})$ in a Waring blender following the standard procedure. This solution was treated as standard plant extract of $100 \%$ concentration.

\subsection{In vitro antifungal assay of botanicals}

Fungitoxic properties of plant extracts against $P$. digitatum and $P$. italicum were tested at (5, 10 and 15)\% concentrations using the poisoned food technique [5] under in vitro conditions. A known amount of each extract was separately mixed with molten PDA and poured aseptically into sterile Petri plates. An agar disk ( $5 \mathrm{~mm}$ diameter) from a 7-d-old actively growing culture of $P$. digitatum and $P$. italicum was placed in the center of the solidified surface of the medium in individual PDA plates. Control plates were also maintained: the culture discs were grown under the same conditions on PDA without extracts. Petri plates were incubated at $(25 \pm 1)^{\circ} \mathrm{C}$. Each treatment was replicated thrice.
Observations were taken when the growth of the culture in control covered the entire Petri plate. The \% inhibition in mycelial growth over control was calculated as:

$\mathrm{I}=[(\mathrm{C}-\mathrm{T} / \mathrm{C}) \times 100]$, where $\mathrm{I}=\%$ inhibition; $\mathrm{C}=$ colony diameter in control $(\mathrm{mm})$ and $\mathrm{T}=$ colony diameter in treatment $(\mathrm{mm})$.

\subsection{In vivo antifungal assay of botanicals}

Mature Kinnow mandarin fruits without any visible defects were obtained from a farmer's orchard located in Abohar, Punjab, India. In the laboratory, fruits were washed with sodium hypochlorite $(0.5 \%)$, rinsed with distilled water and air-dried at ambient temperature $\left(25-28{ }^{\circ} \mathrm{C}\right)$. Surface-sterilized fruits were pricked through the 'pin prick method' up to a depth of $2 \mathrm{~mm}$, making five wounds per fruit [4]. These fruits were inoculated separately by dipping them in spore suspension $\left(10^{6}\right.$ conidia $\left.\cdot \mathrm{mL}^{-1}\right)$ of either of the pathogens $P$. italicum or P. digitatum, then held at room temperature $\left(25^{\circ} \mathrm{C}\right)$ for 2 min. Each plant extract (at 15\%, the highest concentration obtained from the in vitro studies) was used for dipping the fruits [6]. The fruits were first inoculated and then treated with plant extract. Parallel control with fruits dipped in sterile distilled water was also maintained simultaneously. Each treatment was replicated thrice, with seven fruits in each replication. The experiment was framed in factorial completely randomized design (CRD). The inoculated fruits were kept separately in pre-sterilized plastic crates and stored at $(5 \pm 1)^{\circ} \mathrm{C}$ and $85-$ 90\% RH.

The effect of botanicals on various pathological and physiological parameters was evaluated at regular intervals for 60 days during cold storage. Decay incidence (DI) data were expressed as the percentage of fruits showing particular disease symptoms out of the total number of fruits in each treatment, while lesion diameter and decay area were expressed accordingly [7]; other physical, physiological and quality parameters such as physiological loss in weight (PLW) and fruit decay were also assessed. Thirty fruits were used for study. 


\subsection{Fruit decay and storage life of uninoculated Kinnow fruits}

In this experiment, Kinnow fruits collected from the orchards were not inoculated with any pathogen but they were treated with botanicals, then stored at $(5 \pm 1){ }^{\circ} \mathrm{C}$ and $85-90 \% \mathrm{RH}$ to observe the process of fruit decay and the storage life of Kinnow fruits affected by natural infection of $P$. digitatum and $P$. italicum.

\subsection{Determination of respiration and ethylene evolution rates}

Ethylene production and respiration rates were measured using the static headspace technique [8]. Two fruits from each replication were selected at random and enclosed in a hermetically sealed container $(1,000 \mathrm{~mL})$, fitted with a silicon rubber septum, for $1 \mathrm{~h}$ or less. The concentrations of $\mathrm{O}_{2}$ and $\mathrm{CO}_{2}$ were recorded in the headspace of the container using an auto gas analyzer (Model: Checkmate $9900 \mathrm{O}_{2} / \mathrm{CO}_{2}$, PBI Dan sensor, Denmark) and expressed as $\mathrm{mL} \mathrm{CO} \cdot \mathrm{kg}^{-1} \cdot \mathrm{h}^{-1}$. To determine ethylene production, one $\mathrm{mL}$ of the headspace atmosphere of the container was withdrawn with a gas-tight syringe and injected into a gas chromatograph (Model HP 5890, Hewlett Packard, USA) which was calibrated using standard ethylene gas (Laser Gases, New Delhi, India). The gas chromatograph was equipped with a Porapak-N (80-100 mesh) column and a flame ionization detector (FID). Nitrogen was used as the carrier gas at a flow rate of $30 \mathrm{~mL} \cdot \mathrm{min}^{-1}$, while hydrogen and air were the fuel gases with flow rates of (25 and 250) $\mathrm{mL} \cdot \mathrm{min}^{-1}$, respectively. The temperatures in the injector, column and detector were maintained at $(110,60$ and 275$){ }^{\circ} \mathrm{C}$, respectively, and the rate of ethylene evolution was expressed as $\mu \mathrm{L} \cdot \mathrm{kg}^{-1} \cdot \mathrm{h}^{-1}$.

\subsection{Weight loss and fruit decay}

Weight loss was measured by subtracting the initial fruit weight from the final weight; it was expressed as a percentage (\%). Similarly, decay was determined by counting the number of rotten fruit, divided by the total number of fruit, and was expressed as a percentage (\%). Weight loss and decay were determined in 20 fruits per treatment at each storage interval. Fruit firmness was determined using a texture analyzer (Model TA+Di, Stable Microsystems, Godalming, UK) and a compression test. Each fruit sample $(n=5)$ was compressed using a cutting probe as well as a puncture probe at a pre-test speed of $5 \mathrm{~mm} \cdot \mathrm{s}^{-1}$, a test speed of $0.5 \mathrm{~mm} \cdot \mathrm{s}^{-1}$, and a post-test speed of $10 \mathrm{~mm} \cdot \mathrm{s}^{-1}$; it was expressed in Newtons $(\mathrm{N})$.

\subsection{Antioxidant capacity}

Antioxidant (AOX) capacity in Kinnow mandarin was determined by the CUPRAC method [9] with $1.0 \mathrm{~mL}$ of $10 \mathrm{mM}$ copper (II) chloride, $1.0 \mathrm{~mL} 7.5 \mathrm{mM}$ neocuproine (alcoholic solution), $1.0 \mathrm{~mL} 5 \mathrm{mM}$ ammonium aqueous buffer ( $\mathrm{pH} 7$ ), and $1.0 \mathrm{~mL}$ water mixed with $0.1 \mathrm{~mL}$ of each fruit sample (prepared as above), or a standard solution, and the absorbance was read after $30 \mathrm{~min}$ in a spectrophotometer (PerkinElmer UV-VIS Lambda-25) at $450 \mathrm{~nm}$. A standard calibration curve was constructed for each antioxidant compound. The molar absorption coefficient of the CUPRAC method for each antioxidant was found from the slope of the calibration line concerned and antioxidant activities were expressed as $\mu \mathrm{mol}$ Trolox $\cdot \mathrm{g}^{-1}$ fresh weight fruit.

\subsection{Statistical design and analysis of data}

The experiments were laid out in factorial CRD design with each treatment consisting of 30 fruits with three replications. The data obtained from the experiments were analyzed as per design and the results were compared from ANOVA by calculating the critical difference (CD) [10]. For data on decay initiation, decay and shelf life, Duncan's Multiple Range Test was applied. 


\section{Results and discussion}

\subsection{In vitro studies}

\subsubsection{Effects of botanicals on colony diameter of test pathogens}

Our studies indicated that growth (colony diameter) of both Penicillium italicum and $P$. digitatum was inhibited strongly under in vitro conditions by all the botanicals tested, but this inhibition was higher in P. italicum than $P$. digitatum (table I). Among the different botanicals, maximum inhibition was brought out by Aloe vera both in $P$. italicum $(1 \mathrm{~mm})$ and P.digitatum $(3 \mathrm{~mm})$, respectively. This difference in growth inhibition of $P$. italicum and $P$. digitatum could possibly be due to the fact that even though both pathogens grow at the optimal temperature of $24^{\circ} \mathrm{C}$, green mold is predominant at room temperature, and blue mold is more significant in cold conditions, since $P$. italicum grows faster than $P$. digitatum below $10{ }^{\circ} \mathrm{C}$ [11]. Our results agree with those of Sataraddi et al., who reported that maximum inhibition of mycelial growth of fungus was observed in eucalyptus extract followed by garlic extract at $10 \%$ concentration, respectively [12]. Similarly, Tasiwal et al. reported that the extract of Lantana camara at $7.5 \%$ was found to be superior, followed by turmeric at $7.5 \%$ in inhibiting mycelial growth in vitro against anthracnose of papaya [13]. However, contrary to our findings, Patel and Joshi reported that Tulsi leaf extract was ineffective in inhibiting the mycelial growth of fungus [14]. Sharma and Gaur reported the potential of plant extracts (Aloe, Ocimum and Eucalyptus) under in

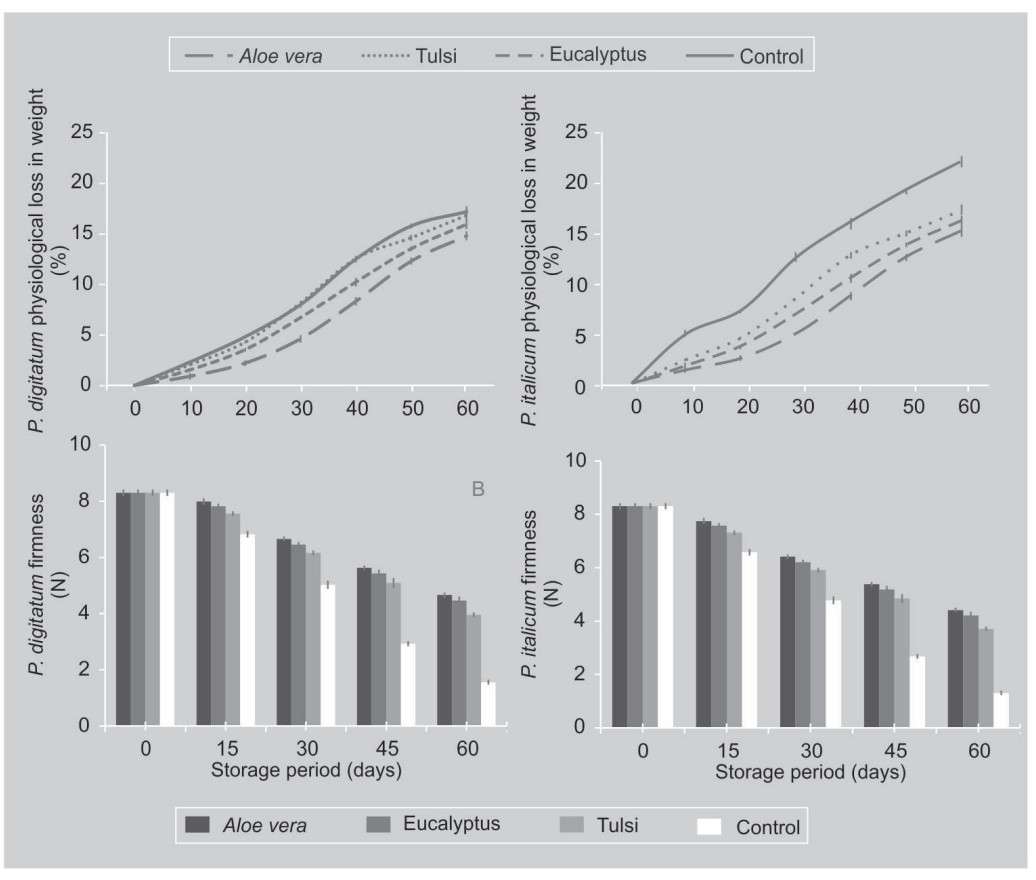

vitro conditions to inhibit the growth of Figure 1.

green mold fungus in Kinnow mandarin [6]. Effect of botanicals on physiological loss in weight and fruit firmness in Kinnow mandarin fruits pre-inoculated with Penicillium digitatum and $P$. italicum, respectively. Fruits were stored at $(5 \pm 1)^{\circ} \mathrm{C}$ and

\subsubsection{Physiological loss in weight}

Our studies revealed a steady increase in physiological loss in weight with the increase in the storage period from the 10th day to the 60th day (figure 1). Similarly, the botanical-treated Kinnow fruits showed lower loss in weight in comparison with untreated fruits, which indicates that botanical-treated fruits can be stored for a longer

\section{Table I.}

Effect of three botanicals incorporated into potato dextrose agar on the growth of pathogens after 10 days of incubation at $25^{\circ} \mathrm{C}$ (mean of five replicates).

$\begin{array}{lcc}\text { Botanicals } & \text { Colony diameter } \\ (\mathrm{mm}) & \text { Penicillium italicum } \\ \text { Aloe vera } & \text { Penicillium digitatum } & 1 \\ \text { Eucalyptus } & 3 & 19 \\ \text { Ocimum } & 23 & 48 \\ \text { Control } & 55 & 67\end{array}$


time than untreated fruits. Similarly, the physiological loss in weight was higher in fruits pre-inoculated with the pathogens causing blue mold than in those causing green mold, indicating that the fruits with $P$. digitatum can be stored longer. Further, the fruits which were pre-inoculated and simultaneously treated with botanicals showed lower loss in weight, the least being with Aloe vera, significantly followed by Eucalyptus- and Ocimum-treated fruits (figure 1). The positive effects of botanicals on decreasing the weight loss could be attributed to a lower respiration rate and ethylene production rate, which might have inhibited the water loss from fruits. The mechanism for these positive effects is based on their hygroscopic properties, which enable formation of a barrier to water diffusion between the fruit and the environment, thus avoiding its external transference. Aloe vera gel contains mainly polysaccharides and is highly effective as a moisture barrier without lipid incorporation. Reduction in physiological loss in weight of strawberry fruits due to Aloe vera gel coatings was also reported by Martinez-Romero et al. [15]. Being hygroscopic in nature it reduces the physiological loss in weight of fruits to a greater extent. Marpudi et al. reported that papaya fruit treated with Aloe vera gel (50\%) showed reduced weight loss (26\%) compared with control (32\%) during storage at $(30 \pm 3){ }^{\circ} \mathrm{C}$ for 10 days [16]. 'Granny Smith' and 'Red Chief' apples coated with Aloe vera gel [(1, 5 and $10 \%, \mathrm{w} / \mathrm{v}$ ] showed lower loss in weight compared with control during storage at $2{ }^{\circ} \mathrm{C}$ for 6 months [17].

\subsubsection{Fruit firmness}

Fruit softening is attributed to the degradation of cell wall components, mainly pectin, due to the action of specific enzymes such as polygalacturonase. Firmness was significantly higher in the botanical-treated fruits than in the untreated ones (figure 1). Fruits pre-inoculated with the pathogen causing blue mold ( $P$. italicum) lost firmness more quickly than those pre-inoculated with $P$. digitatum, giving the impression that the fruits with $P$. digitatum retained higher firmness and can be stored longer. The retention of fruit firmness may be because this coating slowed down the metabolism and prolonged the shelf life. Further, the firmness of Kinnow fruits pre-inoculated with pathogens and simultaneously treated with botanicals was higher than untreated fruits. Among the different botanicals, fruits that received Aloe vera showed higher firmness than the other botanicals; such positive effects of Aloe could be explained from the various results which have shown that the Aloe vera gel excelled as it retains the firmness of many fruits due to its activity against cell wall-degrading enzymes such as polygalacturonases, pectinmethylesterases and $\beta$-galactosidases.

Studies carried out by Mosch et al. reported that plant extracts, besides controlling pathogens, induce several host defense mechanisms such as certain enzymatic activities [18]. However, the explanation for sweet cherry firmness maintenance by Aloe vera coating was related to the lower weight loss, as has been reported in strawberry and apple with different edible coatings [15]. The effect of Aloe gel coating on table grape firmness resulted in a delayed softening process [16, 19].

Further, Ergun and Satici reported that coating of apple and strawberry fruit with Aloe vera gel significantly suppressed the loss of firmness [17].

\subsubsection{Rate of ethylene evolution}

Ethylene evolution is a major deterrent for the postharvest life of any fruit. In Kinnow mandarin, irrespective of the storage period, ethylene evolution was significantly higher in the untreated fruits than the treated ones. However, the fruits pre-inoculated with the pathogens causing green and blue mold showed an increasing trend of ethylene evolution, but $P$. digitatum-inoculated fruits showed less evolution than P. italicuminoculated fruits (figure 2). In fact, there is always a linear correlation between ethylene and damage, and thus the fungus is responsible for the majority of ethylene production. Hence, the higher production rate of ethylene by P. italicum pre-inoculated Kinnow fruits might be due to a greater 

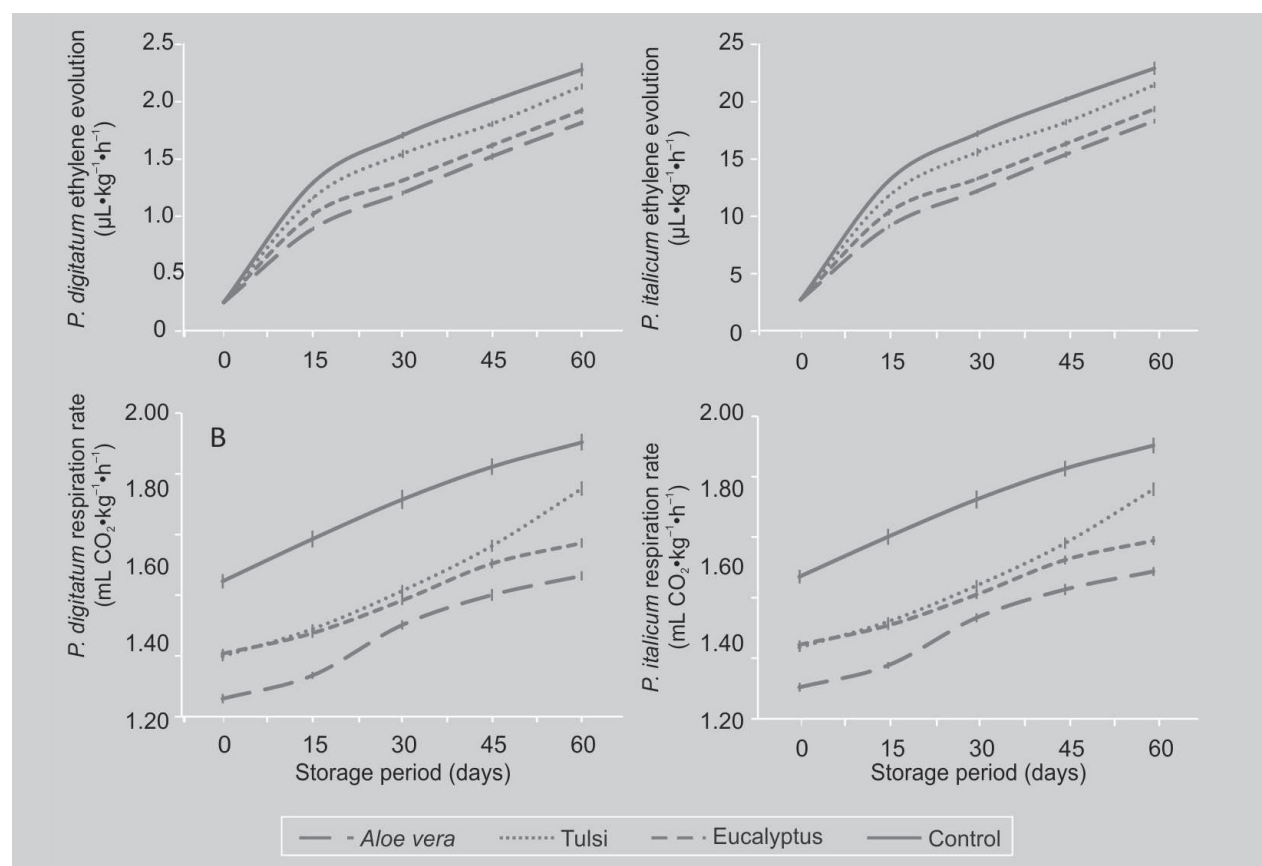

decay area, decay incidence and lesion diameter by the pathogen [20].

Further, Kinnow fruits receiving treatment with Aloe vera showed the lowest ethylene evolution rate, significantly followed by the Eucalyptus and Ocimum treatments. Interestingly, the ethylene production rate was quite steady from the 15 th day onwards but botanical-treated (Aloe vera, Eucalyptus and Ocimum) fruits showed very meager evolution of ethylene up until the 30th day of storage (figure 2). Similarly, the ethylene production rate increased with progressive increase in the storage period from the 15 th day to the 60th day. Little scientific evidence is available on the effect of botanicals on the ethylene production rate. However, Valverde et al. reported that the ethylene production in table grapes coated with Aloe vera gel showed significantly lower evolution in treated fruits $\left(0.45 \mathrm{~nL} \cdot \mathrm{g}^{-1} \cdot \mathrm{h}^{-1}\right)$, compared with control $\left(0.90 \mathrm{~nL} \cdot \mathrm{g}^{-1} \cdot \mathrm{h}^{-1}\right)$ [19].

\subsubsection{Rate of respiration}

The respiration rate is a major metabolic process taking place in harvested produce or in any living plant product. It is one of the basic processes of life, which is directly related to maturation, handling, transportation and subsequent storage life.
The respiration rate was significantly higher in the untreated fruits than the treated ones (figure 2). Fruits pre-inoculated with the pathogen causing blue mold ( $P$. italicum) respired more than those inoculated with $P$. digitatum, giving the impression that the fruits with $P$. digitatum can be stored longer. This could be attributed to the greater tolerance of $P$. digitatum to cold storage conditions $\left[(5 \pm 1)^{\circ} \mathrm{C}\right]$ in which we stored the fruits for our study. Further, the respiration rate of Kinnow fruits preinoculated with pathogens and simultaneously treated with botanicals was lower than that of untreated fruits. Among the different botanicals, fruits that received Aloe vera showed a lower respiration rate than the other botanicals, which could be related to the Aloe vera's retarding action of the ripening process by creation of a modified atmosphere around the fruit surface (figure 2). Our results agreed with the results on 'Crimson Seedless' grape when coated with Aloe gel, which significantly reduced the respiration rate $\left(13.14 \mathrm{mg} \cdot \mathrm{kg}^{-1} \cdot \mathrm{h}^{-1}\right)$ compared with control $\left(19.03 \mathrm{mg} \cdot \mathrm{kg}^{-1} \cdot \mathrm{h}^{-1}\right)$ [19]. Similarly, Martínez-Romero et al. reported that sweet cherry (cv. StarKing) treated with Aloe vera gel showed a significantly lower respiration rate than control during storage at $1^{\circ} \mathrm{C}$ for 16 days [15].
Figure 2.

Ethylene evolution and respiration rate in Kinnow mandarin fruits pre-inoculated with Penicillium digitatum and $P$. italicum as affected by botanicals. Fruits were stored at $(5 \pm 1)^{\circ} \mathrm{C}$ and $85-90 \% \mathrm{RH}$ for 60 days. Data are the means of 30 fruits across three replications. Vertical bars are the standard deviations. 


\section{Figure 3.}

Effect of botanicals on antioxidant capacity and titratable acidity in Kinnow mandarin fruits pre-inoculated with Penicillium digitatum and $P$. italicum. Fruits were stored at $(5 \pm 1)^{\circ} \mathrm{C}$ and $85-90 \% \mathrm{RH}$ for 60 days. Data are the means of 30 fruits across three replications. Vertical bars are the standard deviations.

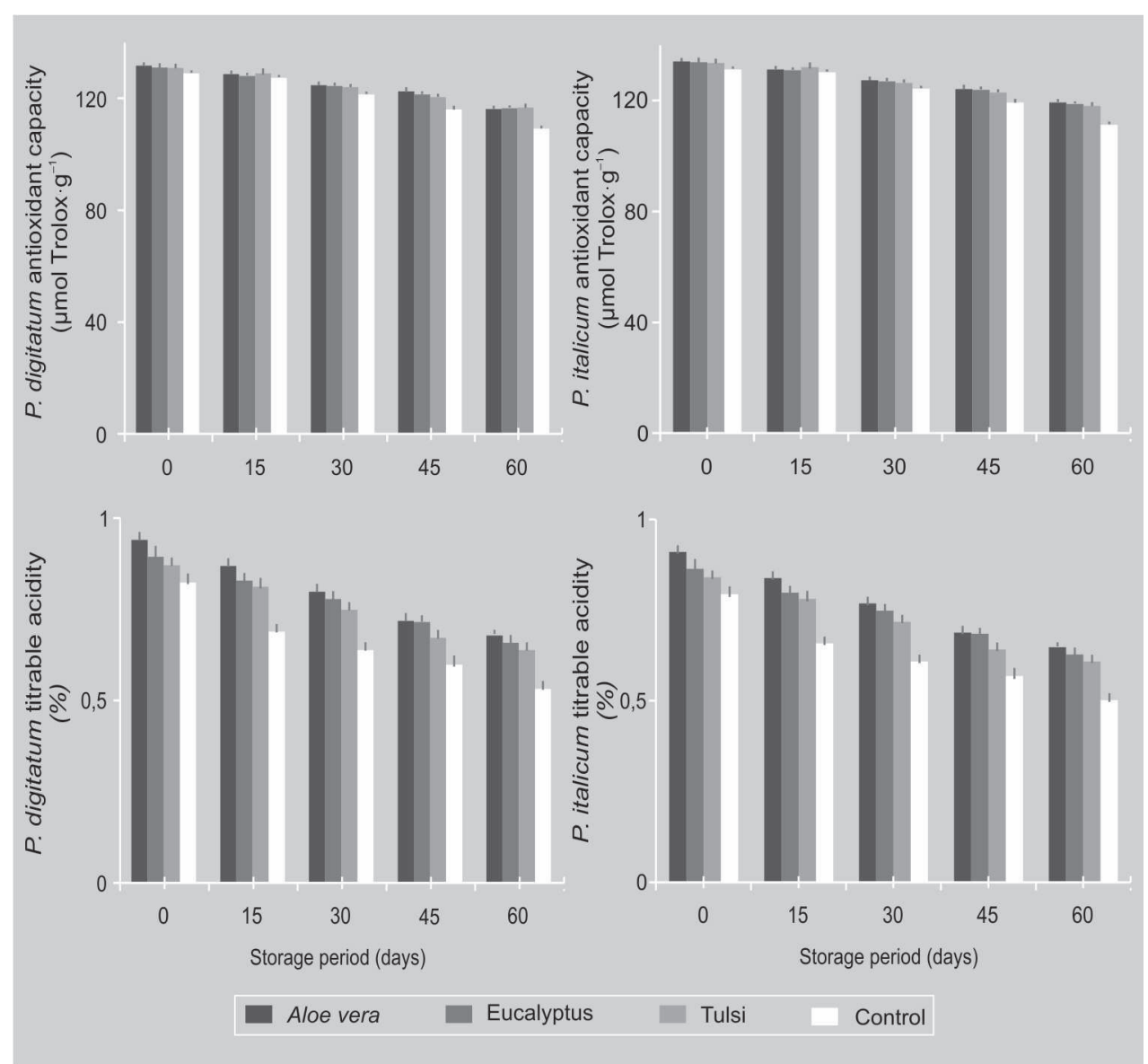

\subsubsection{Antioxidant capacity}

Antioxidant capacity was not much affected by the botanical treatment. Fruits pre-inoculated with the pathogen causing blue mold (P. italicum) had a similar amount of antioxidants in comparison with the fruits inoculated with $P$. digitatum. Further, the antioxidant amounts went on decreasing with the increase in the storage period (figure 3). Our studies were similar to that of Serrano et al., who reported that, in 'Crimson Seedless' grapes treated with Aloe vera gel (1:3 diluted with distilled water), antioxidant capacity remained unchanged and later slight diminution was recorded up to 35 days of storage [21]. The act of antioxidants only diminishing at the end of storage is also a function of botanicals which can be explained by the presence of various secondary metabolites such as tannins, terpenoids, alkaloids and flavonoids [22] derived from plants. However, the antioxidant capacity of plant produce is mainly contributed by the presence of pigments, vitamins (ascorbic acid) and polyphenolics. There are reports that ascorbic acid and phenolics are responsible for antioxidant capacity, either alone or in combination.

\subsection{Quality attributes}

\subsubsection{Titratable acidity}

In Kinnow mandarin, the titratable acidity was significantly higher in the botanicaltreated fruits than in the untreated ones; fruits pre-inoculated with the pathogens causing green and blue mold showed a steady decreasing trend of titratable acidity (figure 3). Kinnow fruits receiving treatment with Aloe vera showed the highest retention of titratable acidity, significantly followed by those treated with Eucalyptus 


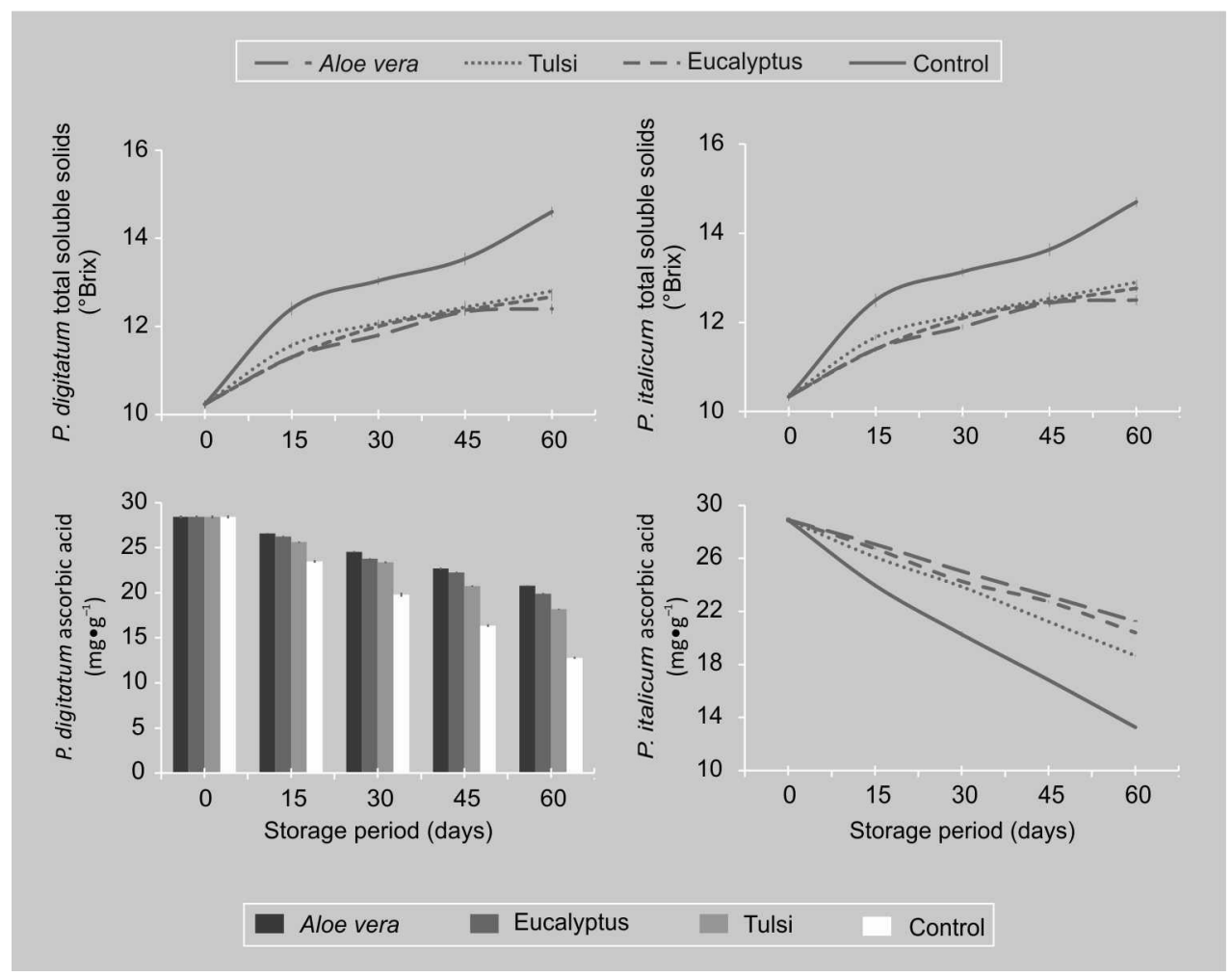

Figure 4.

Effect of botanicals on TSS and ascorbic acid in Kinnow mandarin fruits pre-inoculated with Penicillium digitatum and $P$. italicum. Fruits were stored at $(5 \pm 1)^{\circ} \mathrm{C}$ and $85-90 \% \mathrm{RH}$ for 60 days. Data are the means of 30 fruits across three replications. Vertical bars are the standard deviations.

and Ocimum. Similarly, titratable acidity decreased with the progressive increase in the storage period from the 15th day to the 60th day (figure 3). Further, Penicillium digitatum pre-inoculated fruits showed higher retention of titratable acidity than $P$. italicum pre-inoculated fruits. Hence, the decline in titratable acidity in P. italicum pre-inoculated Kinnow fruits might be related to the reduced ripening index and in turn, maintenance of titratable acidity, while the greater decay area, decay incidence and lesion diameter caused by the pathogen should also not be neglected [11]. Our results confirm the findings of Martínez-Romero et al., who observed that the titratable acidity content of sweet cherry fruit was significantly higher in Aloe vera gel-coated fruit compared with control, during storage at $1{ }^{\circ} \mathrm{C}$ for up to 16 days [15]. Aloe vera gel treatment of strawberry fruit followed by cold storage at $5^{\circ} \mathrm{C}$ was shown to maintain significantly higher titratable acidity (1.37\%) compared with control (0.83\%). Similarly, papaya fruits, when treated with Aloe vera gel (50\%), showed delayed reduction in titratable acidity compared with control [16].

\subsubsection{Total soluble solids}

The total soluble solids content of a fruit gives an account of its sweetness. Our study revealed a steady increase in total soluble solids content with the increase in the storage period from the 15 th day to the 60 th day. Botanical-treated Kinnow fruits showed a steady increase in total soluble solids content in comparison with untreated fruits. This increase in total soluble solids content was less steady in fruits which were preinoculated with Aloevera, followed by those treated with Eucalyptus and Ocimum (figure 4 ). The positive effects of botanicals on maintaining the total soluble solids content could be attributed to the lower respiration and ethylene production rate, which might have inhibited the water loss from fruits, as botanicals form a thin film surrounding the fruit peel and induce a modification of the microclimate of fruits [15]. The effects of botanicals on the quality of fresh horticultural perishables are affected by factors 
related to the type of botanical and its concentration, the produce itself (e.g., species, cultivar, fruit physical and physiological condition) and the postharvest handling (e.g., postharvest treatments, length and environmental conditions of storage) [1].

Nevertheless, Ergun and Satici observed that for apple fruit coated with Aloe vera gel $[(1,5$ and 10$) \%, \mathrm{w} / \mathrm{v}]$ and stored at $2{ }^{\circ} \mathrm{C}$ for 6 months, the total soluble solids content of fruit declined slightly [17]. However, this decline was much slower compared with control. On the contrary, Aloe vera gel applied preharvest did not exert any effect on the total soluble solids content in grapes [22]. The effect of Aloe vera gel (50\%) treatment on the total soluble solids content of papaya fruit delayed the increase in the total soluble solids content compared with control [16].

\subsubsection{Ascorbic acid contents}

Kinnow mandarin is known for its ascorbic acid content. Ascorbic acid was significantly higher in the botanical-treated fruits than in the untreated ones. Fruits pre-inoculated with the pathogen causing blue mold (P. italicum) lost ascorbic acid more quickly than those pre-inoculated with $P$. digitatum, giving the impression that the fruits with $P$. digitatum retained higher ascorbic acid contents and can be stored longer (figure 4). This could be attributed to the tolerance of $P$. digitatum to cold storage conditions $\left[(5 \pm 1){ }^{\circ} \mathrm{C}\right]$ in which we stored the fruits for our study. Among the different botanicals, fruits that received Aloe vera showed higher ascorbic acid contents than the other botanicals. Such differences in retention of ascorbic acid among the different botanicals could be due to their differential influence on initiation of decay rot, which might have helped in maintaining fruit quality and prolonging shelf life or storage life. In addition, the botanical coatings in general, and the Aloe coating in particular, could produce a modification of the internal atmosphere, showing similar effects to sweet cherry fruit under modified atmosphere packaging (MAP) conditions [15]. However, reports are available that Aloe vera gel treatment of strawberry fruit maintained higher sensory qualities in terms of taste, aroma and flavors, during storage at $5{ }^{\circ} \mathrm{C}$ for 16 days.

Similarly, sweet cherry fruit treated with Aloe vera gel maintained higher overall sensory qualities compared with control, for up to 16 days of storage [15]

\subsection{Effect of botanicals on Kinnow fruits pre-inoculated with Penicillium digitatum and $P$. italicum}

\subsubsection{Decay area}

Irrespective of the storage period, botanicaltreated Kinnow fruits showed a smaller mean decay area than untreated fruits, when they were simultaneously pre-inoculated with $P$. digitatum and $P$. italicum. Among the different treatments, fruits treated with Aloevera had the smallest decay area caused by either $P$. digitatum or $P$. italicum, significantly followed by Eucalyptus and Ocimum, with the maximum in untreated fruits (figure 5). Similarly, we noted that fruit decay caused either by $P$. digitatum or $P$. italicum increased with the increase in the storage period from the 30th day to the 60 th day. At the end of the storage period, the decay area caused by $P$. digitatum or $P$. italicum was nearly four times larger than in fruits treated with Aloe vera (figure 5). The effects of the other botanicals (Eucalyptus and Ocimum) on the decay area were also significant over control but were less effective than Aloe vera extracts. The differential response of the botanicals for the decay area caused by $P$. italicum or $P$. digitatum could be attributed to the components and biological activity of the respective botanicals. Thus, the better inhibition of $P$. digitatum and $P$. italicum by Aloe vera may be due to its hygroscopic properties, which enable formation of a barrier to water diffusion between fruit and the external environment, thus avoiding its external transference. Irrespective of the botanical treatment and storage, Penicillium italicum caused a larger decay area than P. digitatum. Although no scientific evidence is available to prove this fact, this could probably be due to the fact that green 


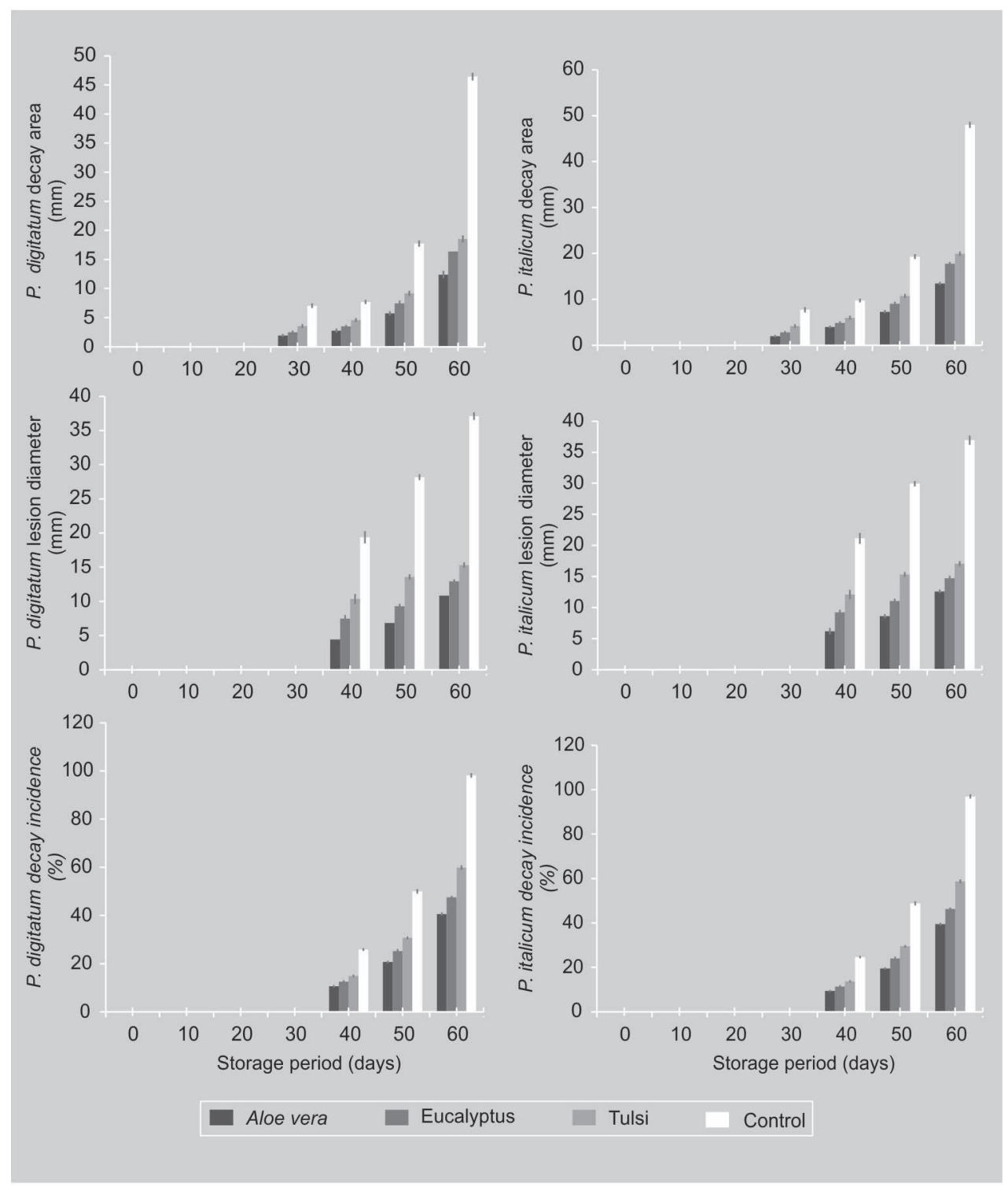

Figure 5.

Effect of botanicals on decay area, lesion diameter and decay incidence in Kinnow mandarin fruits pre-inoculated with Penicillium digitatum and $P$. italicum. Fruits were stored at $(5 \pm 1)^{\circ} \mathrm{C}$ and $85-90 \% \mathrm{RH}$ for 60 days. Data are the means of 30 fruits across three replications. Vertical bars are the standard deviations.

mold is more predominant at room temperature than blue mold and $P$. italicum grows faster than $P$. digitatum below $10^{\circ} \mathrm{C}$ [11].

\subsubsection{Lesion diameter}

Botanical-treated Kinnow fruits showed a smaller lesion diameter than untreated fruits, when they were pre-inoculated with $P$. digitatum and $P$. italicum; the pathogens are known to cause huge postharvest losses in the citrus industry. Among the different treatments, fruits treated with Aloe vera had the smallest lesion diameter caused by either $P$. digitatum or $P$. italicum, followed by Eucalyptus or Ocimum, with $P$. digitatum pre-inoculated fruits showing a smaller lesion diameter (figure 5). Such a positive effect of the botanicals, specifically of Aloe vera, could be attributed to the reason that the predominant anthraquinones (aloin and aloe-emodin) could be important antifungal moieties. Thus, Aloe vera gel, having natural biocidal activity, is effective against the fruit spoilage fungi. However, the lesion diameter showed an increasing 
trend with the increase in the storage period from the 40th day to the 60th day of storage. The use of Aloe vera gel coating, with a formulation under patent [21], was effective in preharvest and postharvest application for the control of postharvest gray mold of table grapes. Clusters sprayed $1 \mathrm{~d}$ before harvest with the Aloe vera gel solution, then stored for $35 \mathrm{~d}$ at $2{ }^{\circ} \mathrm{C}$, had $1 \%$ decayed berries compared with $15 \%$ of those of the control, although additional preharvest sprays did not provide better efficacy [20].

Table grape bunches immersed in grapefruit seed extracts and stored for 4 weeks at $0{ }^{\circ} \mathrm{C}$ had 6 infected berries per kg compared with the 19 infected berries of the control [23]. When bunches were artificially challenged with Botrytis cinerea, there were 18 and 65 infected berries per kg according to whether bunches were treated with grapefruit seed extracts or untreated, respectively [23]. The time of appearance of initial gray mold symptoms was used to evaluate the efficacy of treatments on detached berries which were artificially wounded and inoculated with B. cinerea.

\subsubsection{Decay incidence}

Decay incidence in botanical-treated Kinnow fruits was lower than in untreated fruits when they were simultaneously pre-inoculated with green and blue mold pathogens. Among the different treatments, fruits treated with Aloe vera had the lowest decay incidence followed by Eucalyptus- and Ocimum-treated fruits (figure 5). Various researchers studied and reported that plant extracts have been effective against the fungus $P$. digitatum, which include garlic and neem [6]. For instance, treatment of sweet cherry fruit with Aloe vera gel showed a markedly reduced viable microbial count on it during cold storage at $1{ }^{\circ} \mathrm{C}$ [15]. Similarly, the incidence of diseases in papaya fruit was significantly reduced when they were treated with Aloe vera gel $(50 \%$ and stored at room temperature for 10 days [10]. However, fruit decay of pre-inoculated fruits with $P$. italicum and P. digitatum pathogens increased with the increase in the storage period from the 40th day (0.0\%) to the 60th day of storage, with $P$. digitatum showing lower decay incidence in comparison with $P$. italicum. Interestingly, untreated fruits showed almost 50\% fruit decay on the 50th day of storage, whereas in the best treatment, i.e., with Aloe vera, the fruits did not show such a percentage of decay until the 60 th day of storage. There are some reports on the antifungal activity of $A$. vera gel against several pathogenic fungi including Botrytis cinerea. When applied as an edible coating, A. vera gel maintains the quality and reduces the decay symptoms in freshly harvested fruits. Earlier reports have shown that Aloe reduced spore survival by $15-20 \%$ for Penicillium, Botrytis and Alternaria [1], and accordingly Aloe reduced the mycelium growth of other plant pathogenic fungi such as Rbizoctonia, Fusarium and Colleotrichum by $22-38 \%$, showing a limitation in controlling possible fungal infections. In general, all plant extracts tested during the

Table II.

Efficacy of three botanicals on initiation of decay (days), decay rot (\%) and increase in storage life of uninoculated Kinnow mandarin fruits stored at $5{ }^{\circ} \mathrm{C}$ for 60 days. Data are the mean of 30 fruits across three replications. Means with the same letters in columns are not significant different.

\begin{tabular}{|c|c|c|c|c|c|c|}
\hline \multirow[t]{2}{*}{ Botanicals } & \multicolumn{3}{|c|}{ Penicillium digitatum } & \multicolumn{3}{|c|}{ Penicillium italicum } \\
\hline & $\begin{array}{l}\text { Initiation of } \\
\text { decay } \\
\text { (days) }\end{array}$ & $\begin{array}{c}\text { Decay rot } \\
\text { (\%) }\end{array}$ & $\begin{array}{l}\text { Increase in } \\
\text { storage life } \\
\text { (days) }\end{array}$ & $\begin{array}{l}\text { Initiation of } \\
\text { decay } \\
\text { (days) }\end{array}$ & $\begin{array}{c}\text { Decay rot } \\
(\%)\end{array}$ & $\begin{array}{c}\text { Increase in } \\
\text { storage life } \\
\text { (days) }\end{array}$ \\
\hline Aloe vera & $50 a$ & $33.63 \mathrm{a}$ & $9 a$ & $46 a$ & $37.67 \mathrm{a}$ & $7 \mathrm{a}$ \\
\hline Eucalyptus & $43 \mathrm{~b}$ & $42.57 \mathrm{~b}$ & $7 \mathrm{~b}$ & $43 \mathrm{~b}$ & $44.57 \mathrm{~b}$ & $5 b$ \\
\hline Ocimum & $42 \mathrm{~b}$ & $51.93 \mathrm{c}$ & $6 \mathrm{~b}$ & $41 \mathrm{~b}$ & $56.93 \mathrm{c}$ & $4 \mathrm{~b}$ \\
\hline Control & $33 c$ & $94.97 \mathrm{e}$ & $0 \mathrm{~d}$ & $31 \mathrm{c}$ & $96.97 \mathrm{e}$ & $0 \mathrm{~d}$ \\
\hline
\end{tabular}


study markedly differed in their fungal toxicity, which might be due to a variation in the composition of antifungal compounds and their concentration.

\subsection{Efficacy of botanicals on natural decay development}

Our studies indicated that initiation of decay caused by either $P$. digitatum or $P$. italicum in uninoculated Kinnow mandarin fruits started, respectively, after (33 and 31) days of storage at $5{ }^{\circ} \mathrm{C}$ and $80-90 \%$ RH (table II). Interestingly, initiation of such decay was significantly delayed by all the botanicals. However, decay initiation caused by $P$. digitatum and P. italicum was delayed by 50 days and 46 days, respectively, by Aloe vera. This treatment not only delayed the decay initiation process but also inhibited/ decreased overall decay in Kinnow mandarin fruits, consequently increasing the storage life by (9 and 7) days, respectively (table II). From this study we can see that when the fruits were not inoculated artificially by the pathogens they still contained a natural population of pathogens which cause decay during storage; such decay can also be reduced significantly by botanicals as such treatments have the ability to inhibit the natural decay caused by $P$. digitatum and P. italicum. The present findings confirm the results of Obagwa and Korsten, who achieved good control of fruit decay in Valencia orange incited by $P$. digitatum when fruits were treated with a combination of garlic extract and sunflower oil [23]. Serrano et al. found that the application of Aloe gel could maintain quality and reduced decay symptoms in sweet cherry [21].

In general, all botanicals differed in their fungal toxicity, which could be due to their variation in each individual composition of antifungal compounds and their concentration. However, plants synthesize various secondary metabolites, which possess antimicrobial properties, like for example the compounds aloin and aloe-emodin, which are major constituents of Aloe, and in the leaves of Eucalyptus, cineole, \pm 1-pinenes and $\pm \alpha$-terpineol compounds might have played a role in antifungal activities.
Likewise, Ahmadian and Fakhree reported antifungal activity of henna leaf extract, attributed to their 2-hydroxy-1,4naphthoquinone compound [24]. Fungitoxic properties of turmeric rhizomes attributed to sesquiterpenoids, curcumol and curcumin in rhizomes of turmeric might be responsible for toxicity against pathogenic fungi [25].

\section{Conclusion}

Botanicals have the potential to control green and blue mold diseases caused by $P$. digitatum and $P$. italicum, respectively, in Kinnow mandarin. Mycelial growth was clearly affected by the botanicals used, indicating that these concentrations affected various stages of the development of P. digitatum and P. italicum. Among the botanicals, Aloe vera was found to be by far the best in controlling the incidence of green and blue mold disease. In our investigation, the botanicals maintained the quality of the fruit during their storage. Treated fruits were attractive and their texture was well maintained. Thus, it can be concluded that dipping treatment of Kinnow fruits in an aqueous extract (at 15\%) of Aloe, Ocimum and Eucalyptus leaves would be a cheaper, eco-friendly and effective management strategy for control of postharvest fruit decay caused by $P$. digitatum and $P$. italicum as an alternative to chemical fungicides.

\section{Acknowledgments}

We thank Dr. V.R. Sagar, Head, Division of Postharvest Technology, IARI, New Delhi, for providing all lab facilities. We are also grateful to Dr. Charanjit Kaur, Division of Postharvest Technology, Dr. S.K. Singh, Division of Fruits and Horticultural Technology, New Delhi, and Dr. Madan Pal Singh, Division of Plant Physiology, IARI, New Delhi, for valuable advice during this investigation. The financial support of the ICAR in the form of a Senior Research Fellow is duly acknowledged. 


\section{References}

[1] Saks Y., Barkai-Golan R., Aloe vera gel activity against plant pathogenic fungi, Postharvest Biol. Technol. 6 (1995) 159-165.

[2] Janisiewicz W.J., Korsten L., Biological control of postharvest diseases of fruits, Annu. Rev. Phytopathol. 40 (2002) 411-441.

[3] Bautista-Banos S., Hernandez-Lopez M., Bosquez-Molina E., Wilson C.L., Effects of chitosan and plant extracts on growth of Colletotrichum gloeosporioides, anthracnose levels and quality of papaya fruit, Crop Prot. 22 (2003) 1087-1092.

[4] Eckert J.W., Brown G.E., Postharvest citrus disease and their control, in: Fresh citrus fruits, AVI publ. Co., Westport, 1986, pp. 315-360.

[5] Nene Y.L., Thapliyal P.N., Fungicides in plant disease control, 3rd ed., Oxford \& IBH Publ. Co. Pvt. Ltd., New Delhi, India, 1997, 531 p.

[6] Sharma R.N., Gaur R.B., Potentiality of botanicals against post-harvest fruit decay in Kinnow caused by Penicillium digitatum, Indian J. Plant Prot. 39 (2) (2011) 136-140.

[7] Sivakumar D., Hewarathgamagae N.K., Wijeratnam R.S.W., Wijesundera R.L.C., Effect of ammonium carbonate and sodium bicarbonate on anthracnose of papaya, Phytoparasitica 30 (2002) 1-7.

[8] Jhalegar M.J., Sharma R.R., Pal R.K., Rana V., Effect of postharvest treatments with polyamines on physiological and biochemical attributes of kiwifruit (Actinidia deliciosa) cv. Allison, Fruits 67 (2012) 13-22.

[9] Apak R., Guclu K., Ozyurek M., Karademir S.E., Novel total antioxidant capacity index for dietary polyphenols and vitamins $\mathrm{C}$ and $\mathrm{E}$ using their cupric ion reducing capability in the presence of neocuprine: The CUPRAC method, J. Agric. Food Chem. 52 (2004) 7970-7981.

[10] Panse V.G., Sukhatme P.V., Statistical methods for agricultural workers, ICAR, New Delhi, India, 1984, pp. 288-290.

[11] Brown G.E., Eckert J.W., Penicillium decays, in: Timmer L.W., Gamsey S.M., Graham J.H. (Eds.), Compendium of citrus diseases, 2nd ed., APS, St Paul, MN, U.S.A., 2000, pp. 41-42.

[12] Sataraddi A.R., Prashanth A., Virupaksha Prabhu H., Jamadar M.M., Aski S., Role of bio-agents and botanicals in the management of anthracnose of pomegranate, Acta Hortic. 890 (2011) 381-388.

[13] Tasiwal V., Benagi I., Ashodar Y., Hegde B., Kamanna C., Ramachandranaik K., In vitro evaluation of botanicals, bioagents and fungicides against anthracnose of papaya caused by Colletotrichum gloeosporioides (Penz.) Penz. \& Sacc, Karnataka J. Agric. Sci. 22 (4) (2009) 803-806.

[14] Patel K.D., Joshi K.R., Antagonistic effect of some bioagents in vitro against Colletotrichum gloeosporioides Penz. \& Sacc., the causal agent of leaf spot of turmeric, J. Mycol. Plant Pathol. 31 (2001) 126-129.

[15] Martínez-Romero D., Alburquerque N., Valverde J.M., Guillén F., Castillo S., Valero D., Serrano M., Postharvest sweet cherry quality and safety maintenance by Aloe vera treatment: a new edible coating, Postharvest Biol. Technol. 39 (2006) 93-100.

[16] Marpudi S.L., Abirami L.S.S., Pushkala R., Srividya N., Enhancement of storage life and quality maintenance of papaya fruit using Aloe vera based antimicrobial coating, Indian J. Biotechnol. 10 (2011) 83-89.

[17] Ergun M., Satici F., Use of Aloe vera gel as biopreservative for 'Granny Smith' and 'Red Chief' apples, J. Anim. Plant Sci. 22 (2) (2012) 363-368.

[18] Mosch J., Mende A., Zeller W., Rieck M., Ellrich W., Plant extracts with a resistance induction effect against fire blight (Erwinia amylovora), Acta Hortic. 338 (1993) 389-394.

[19] Valverde J.M., Valero D., Martínez-Romero D., Guillén F., Castillo S., Serrano M.A., Novel edible coating based on Aloe vera gel to maintain table grape quality and safety, J. Agric. Food Chem. 53 (20) (2005) 7807-7813.

[20] Castillo S., Navarro D., Zapata P.J., Guillén F., Valero D., Serrano M., Martínez-Romero D., Antifungal efficacy of Aloe vera in vitro and its use as a preharvest to maintain postharvest table grape quality, Postharvest Biol. Technol. 57 (2010) 183-188.

[21] Serrano M., Valverde J.M., Guillén F., Castillo S., Martínez-Romero D., Valero D., Use of Aloe vera gel coating preserves the functional properties of table grapes, J. Agric. Food Chem. 54 (2006) 3882-3886.

[22] XuW.T., Huang K.L., Guo F., QuW., Yang J.J., Liang Z.H., Luo Y.B., Postharvest grapefruit seed extract and chitosan treatment of table grapes to control Botrytis cinerea, Postharvest Biol. Technol. 46 (2007) 86-94.

[23] Obagwa J., Korsten, L., Control of citrus green and blue molds with garlic extracts, Eur. J. Plant Pathol. 109 (2003) 221-225.

[24] Ahmadian S., Fakhree M.A., Henna (Lawsonia inermis) might be used to prevent mycotic infection, Med. Hypotheses 73 (2009) 629-630.

[25] Rastogi R.P., Mehrotra B.N., Compendium of Indian medicinal plants, Vol. 1-4, C.D.R.I. Lucknow Publ. Inf. Dir., 1993 and 1995, New Delhi, India. 


\section{Eficacia antifúngica de ciertas especies botánicas contra importantes agentes patógenos poscosecha en la mandarina Kinnow y su uso para mantener la calidad poscosecha.}

Resumen - Introducción. La mandarina Kinnow es una importante variedad de cítrico cultivada en la India y es sensible a varias enfermedades poscosecha durante su almacenaje. Por ello, se realizó un intento de combatir las enfermedades de la mandarina Kinnow con la ayuda de especies botánicas, tales como Aloe vera, Eucalyptus y Ocimum y prolongar, de este modo, su disponibilidad. Material y métodos. Se llevaron a cabo estudios in vitro e in vivo. Se empleó la técnica de alimentación contaminada para estudios in vitro y, para los estudios in vivo, se pre-inocularon los frutos de Kinnow con agentes patógenos (Penicillium digitatum y $P$. italicum), tratados con diferentes especies botánicas, a continuación se conservaron a la temperatura de $(5 \pm 1){ }^{\circ} \mathrm{C}$ y $85-90 \%$ de HR. Resultados y discusión. In vitro, nuestros resultados indicaron que cada especie botánica testeada impidió el crecimiento (diámetro de las colonias) de ambos patógenos en las cajas tratadas, en relación con las cajas no tratadas, pero la inhibición fue mayor con los extractos de Aloe vera. Asimismo, en condiciones in vivo, todas las especies botánicas influenciaron la incidencia de pudrición causada por Penicillium sp., las pérdidas ocasionadas por la pudrición, el diámetro de lesión, el índice respiratorio, la evolución del etileno y las pérdidas de peso fisiológicas, pero Aloe vera fue más eficaz. Las tres especies botánicas testeadas pudieron mantener la calidad poscosecha de los frutos de la mandarina Kinnow sin tener un efecto inverso en parámetros como los sólidos solubles totales, la acidez valorable y el ácido ascórbico. Bajo condiciones in vivo, la incidencia de $P$. italicum fue mayor que la de $P$. digitatum, sin embargo, se constató lo contrario bajo condiciones in vitro. Conclusión. Nuestros estudios mostraron de manera evidente que las especies botánicas pueden controlar el moho verde y azul causado por Penicillium sp. sin conllevar daños o efectos nefastos en la mandarina Kinnow. Éstas pueden recomendarse para prolongar la duración de almacenamiento de este fruto, manteniendo simultáneamente su calidad.

India / Citrus / mandarina / frutas / control de plagas (postcosecha) / control biológico / tasa de respiración / aptitud para la conservación 